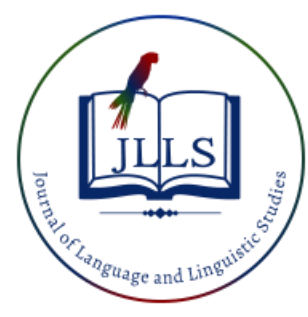

Available online at www.jlls.org

JOURNAL OF LANGUAGE AND LINGUISTIC STUDIES

ISSN: 1305-578X

Journal of Language and Linguistic Studies, 16(3), 1127-1145; 2020

\title{
Effects of second language on motion event lexicalization: Comparison of bilingual and monolingual children's frog story narratives
}

\section{APA Citation:}

\author{
Aslı Aktan-Erciyes a 1 iD \\ ${ }^{a}$ Kadir Has University, Istanbul, Turkey
}

Aktan-Erciyes, A.. (2020). Effects of second language on motion event lexicalization: Comparison of bilingual and monolingual children's frog story narratives. Journal of Language and Linguistic Studies, 16(3), 1127-1145.

Submission Date:24/10/2019

Acceptance Date:08/01/2020

\begin{abstract}
This study investigates how children lexicalize motion event patterns in their first and second languages, L1Turkish and L2-English. English is a satellite-framed language that conflates motion with manner expressed in the main verb and path in a non-verbal element, whereas Turkish is a verb-framed language that conflates motion with path in the main verb and expresses manner in a subordinated verb. We asked whether (1) learning a second language had an effect on children's event descriptions in their first language and (2) the effects were bidirectional. One-hundred-and-twelve 5- and 7-year-old monolingual (L1-Turkish) and bilingual (L1-Turkish; L2-English) children participated. Participants produced narratives for wordless picture book, Frog, where are you? Six scenes of the book were selected for coding purposes as they represented motion events: (1) Frog's exit from the jar, (2) Dog's fall from the window, (3) Gopher popping out of the hole, (4) Owl's exit from a nest, (5) Boy and dog falling down and (6) Boy and dog landing in a pond. For L1 descriptions, 5-year-old bilinguals used more manneronly and less path-only descriptions than monolinguals; no difference was found for 7-year-olds. For L2 descriptions, bilingual children used less Manner-only and more Path-only expressions in their L2 narratives compared to L1 narratives. These findings suggest that for 5-year-olds, exposure to second language had an impact on how motion events are encoded. Results inform us about the early interactions between L1 and L2 in motion event lexicalization
\end{abstract}

(C) 2020 JLLS and the Authors - Published by JLLS.

Keywords: bilingualism; motion event lexicalization; thinking-for-speaking; Turkish; English

\section{Introduction}

Language is a system for converting our thinking into communicable forms such as sounds, gestures or written symbols. Wolff and Holmes (2011) summarize potential ways of how language influences thinking. At one end, thought is regarded as the language itself, whereas at the other end thought is suggested to be separated from language. In the latter view, either language and thought are structurally parallel as suggested by Whorf (1956) or they differ structurally. Whorf (1956) proposed that language is not a mere medium of transmission of thought, but also plays a crucial role in shaping thought itself.

\footnotetext{
${ }^{1}$ Corresponding author.

E-mail address: asli.erciyes@khas.edu.tr
} 
Contrary to this proposal as suggested by recent evidence, language and thought might differ. Slobin (1996) proposes that there is an online effect of language on cognition, which manifests itself when language is in use, that is, in "thinking-for-speaking." In this view, mere translation across languages does not correspond to the same reality. Accordingly, acquiring a language provides the speaker a language specific way of thinking rather than the translation of an objective reality. The present study investigates the effects of early second language exposure on motion event lexicalization and discusses the results within the perspective of Slobin's view of thinking-for-speaking. Specifically, we examine the effects of early and intense exposure to English on motion event lexicalization patterns in L1-Turkish and L2-English in preschool and school-aged children.

\subsection{Literature review}

\subsubsection{Motion event conceptualization and bilingualism}

One of the domains that bilingualism might have projections on, is the specific area of motion event conceptualization. Language is assumed to be a system for converting our thinking into communicable forms such as sounds, gestures or written symbols in order to pass the information to others. It was proposed by Whorf (1956) that language is not a mere medium of transmission of thought but also plays a crucial role in shaping thought itself. A reinterpretation of this view by Slobin (1996) maintains that languages are not "neutral coding systems of an objective reality" (p.91), and that mere translation across languages does not correspond to the same reality. Slobin (1996) proposes that the effect of language on cognition shows itself when language is in use. Slobin proposes that this special kind of thinking that is carried out online provides the speaker with a language specific way of thinking. This phenomenon is called the Thinking-for-Speaking effect in the literature. The present study will be investigating the effects of early L2 exposure on cognition within Slobin's view of Thinking-for-Speaking.

\subsubsection{Cross-linguistic differences in motion event conceptualization}

A formal definition of an event is "a segment of time at a given location that is perceived by an observer to have a beginning and an end" (Zacks \& Tversky, 2001, p.29). Motion events share common features or structures such as: Figure, Ground, Path and Manner. A typology for how motion events are represented across different languages has been proposed by Talmy (1985) whose starting point was the two main features people use in representing a scene: figure and ground. To illustrate, in the boy is walking across the road, the boy is the figure and the road is the ground. Most of the time, these two main features are in the context of a motion event which is described as a "situation that involves displacement of an object in relation to a reference point" (Bylund, 2011, p.109). Although motion events are universally central to human life across cultures, languages vary greatly in how they represent and express information regarding motion and encode path (the trajectory of the motion/action with respect to the ground such as over, under etc.) and manner (the way the motion/action takes place, such as jumping, rolling etc.). Talmy's typology $(1985,2000)$ offers a categorization of languages based on mappings of these universal meaning components onto common surface elements such as verbs, adverbials etc. Accordingly, languages fall into two main types based on how motion events can be described: (1) Verb-framed languages and (2) Satellite-framed languages. In verb-framed languages such as Turkish, the path or trajectory of the motion is readily encoded in the main verb çı- 'exit' (e.g., çocuk bahçeye çıktı 'the boy exited to the garden'), and the manner of the motion is often left implicit; however, in satellite-framed languages such as English, manner is encoded in the main verb but path is encoded outside the main verb (often in adjuncts). For example, in Talmy's (1985, p.102) prototypical example the bottle floated out of the cave, the verb float expresses the manner of movement; and the path is expressed in out of which is depicted in the prepositional phrase. The primary differences between these two types are syntactic frames where manner and path are encoded and the fact that encoding of manner is optional in verb-framed languages. 
This typology has been investigated in studies covering a wide range of languages including Turkish, Spanish and English in both written and oral narratives (e.g. Özçalışkan \& Slobin, 2003; Slobin, 1996, 2006, among others), in elicited narratives (Berman \& Slobin, 1994; Naigles et al., 1998; Özçalışkan \& Slobin 1999; Slobin, 1991, 2004) and in translations of novels (e.g. Slobin, 2005), within the thinkingfor speaking framework. These studies have revealed interesting differences between languages. Crosslinguistic studies conducted by Slobin and associates show that individuals whose native language is satellite-framed (such as English) represent manner and directed motion as a single concept whereas the users of verb-framed languages (such as Turkish) put little emphasis on manner (often left implicit) but focus on path (Berman \& Slobin, 1994; Slobin, 1996, 2000). For example, Özçalışkan and Slobin (1999) have found that 3-year-old children learning a verb-framed language such as Turkish or Spanish used more path verbs (e.g. exit), compared to children learning English (a satellite-framed language) who used more manner verbs (e.g. fly) in narratives they produced for a picture storybook (Frog, Where are you?, Mayer, 1969). The same pattern was also found for 3-year-old children in Korean versus English (Oh, 2003) and adult speakers of English and Greek (Papafragou, Massey, \& Gleitman, 2002)

\subsubsection{Motion event conceptualization in second language learners}

The cross-linguistic differences in motion event conceptualization is evident in the literature, however the effects of learning a second language, which frames motion events differently than the first language is another important issue. In explaining the relationship between two languages and concepts in the same mind, Cook (2015) proposes that L1 affects L2 in all aspects of language but the effects of L2 on L1 is also evident (Cook, 2003).

Recent studies on event conceptualization in second language learners point to bidirectional effects of L1 and L2. Pavlenko and Volynsky (2015) investigated effects of L2-English on L1-Russian with Russian monolingual, English monolingual and Russian-English bilingual adults with a narrative elicitation task. Both languages are satellite-framed, however have differences in motion event conceptualizations; encoding manner in English is optional compared to Russian where it is obligatory in most contexts (e.g. certain verbs have specific adverbials that are used together). Therefore, it was suggested that even though both languages are satellite-framed; the degree of emphasis put on manner encoding might have an effect on L2 learners' event conceptualization. Bilingual undergraduate participants displayed language specific patterns in both languages for path, one-segment clauses (path is expressed in one linguistic unit such as a verb) in L2-English and two-segment path clauses (path is expressed in two linguistic units such as preposition used in form of a prefix like "up-lifting") in L1Russian. L1-Russian speakers segmented motion events in a more fine-grained fashion compared to L1 English speakers. In Russian narratives of L1-Russian- L2-English bilinguals, there were less manner verbs compared to L1-Russian monolinguals' narratives. Thus, having been exposed to a language that puts less emphasis on manner had an effect on L1 event conceptualization. In the same vein, Hasko (2009) compared L1-Russian and L1-English -L2-Russian speakers" "Frog story" narratives and found that in L2 learners' narratives, there was a high percentage of errors in path encoding and insufficient encoding of manner compared to L1 Russian speakers' narratives. For languages that are different in terms of Talmy's categorization, findings of bilingual motion event conceptualization also support Thinking-for-Speaking effect. For instance, Brown and Gullberg (2008) found fewer mentions of manner in L2-English (satellite-framed) discourse by L1 Japanese (verb-framed) bilingual adults compared to L1 English monolingual narratives and suggested that this was due to L1 transfer. Flecken, Weimar, Carroll and Von Stutterheim (2015) investigated differences in spatial conceptualization in French (verb-framed) and German (satellite-framed). In French when expressing direction of movement, specific relations such as alignment and distance toward are given in the path verbs which lexically convey this information, however in German, this is not the case. German has mainly manner verbs in the lexicon. L1-French, L1-German and L2-German speakers were tested in a paradigm where their 
attention allocation was measured via eye tracking. Participants viewed an event description task where moving entities and endpoints in motion scenes were displayed. The results showed that L1-French participants allocated more attention to entities in motion and endpoints (before onset of utterance) compared to L1-German speakers. The L2-German speakers' pattern was similar to L1-German speakers in the use of manner verbs but since they had not fully acquired spatial language (due to AoO which is greater than 10) and ways to structure path of the motion, their pre-articulatory attention allocation patterns were similar to L1-French speakers. In a recent study, Brown (2015) investigated bilingual versus monolingual construal of manner in speech and gesture across three languages, Mandarin (equipollent -neither verb nor satellite-framed), Japanese (verb-framed) and English (satellite-framed), which are proposed to be typologically distinct in speech and co-speech gesture (Brown \& Chen, 2013, Slobin, 2004). According to Talmy's categorization, Japanese is a verb-framed language (encoding manner outside the verb) and English is a satellite-framed language (encoding manner within the verb); Mandarin on the other hand, is considered to be in between where path and manner are expressed by "equipollent" (equal in linguistic forms) elements. Participants viewed a Sylvester and Tweety Bird cartoon and were asked to orally describe scene-by-scene presentation of the cartoon as they watched. Bilingual L1-Japanese- L2-English speakers displayed fewer mentions of manner in L2-English compared L1-English monolingual speakers and more mentions of manner than L1-Japanese speakers as a consequence of L2-English. Furthermore, they did not differ in their two languages for manner descriptions. For L1-Mandarin-L2-English bilinguals, there were fewer manner mentions in their L2 than monolingual speakers of both Mandarin and English. Results concerning differences in gesture use accompanying manner mentions showed that bilingual Mandarin-English speakers marked manner in gestures more than monolingual speakers of each language. As a result, Brown (2015) claims that L2 users have a unique pattern (neither like L1 nor like L2) of gestures revealed both in their $\mathrm{L} 1$ and $\mathrm{L} 2$.

The age of onset also had an influence, indicating that early bilinguals showed an L2 to L1 effect; Hohenstein, Eisenberg and Naigles (2006), investigated how L1-Spanish (verb-framed) - L2-English (satellite-framed) adult bilinguals (nearly half were early bilinguals AoO being less than 10 years and others were late bilinguals) described motion events that they watched compared to English and Spanish monolinguals. It was found that bilinguals used more manner verbs than path verbs in their descriptions of events both in Spanish and English. When L2-English event descriptions of L1-Spanish - L2-English bilinguals were compared to L1-English monolinguals' descriptions, fewer mentions of manner were observed. The age of acquisition also had an effect indicating that early bilinguals showed an L2 to L1 effect. The results showed that early bilinguals used fewer path verbs in Spanish (effect of L2-English). In a recent study, Lai, Rodriguez and Narasimhan (2013) tested early and late bilingual (L1-Spanish L2-English) adults on description of motion events. In that paradigm, bilinguals were first asked to describe events in the video clips they watched in one language, which intends to prime the participant that language's mode of thinking. After they described the events, an event classification task was administered. In this task the initial video, which was shown for description, was altered. The new event either was manner-consistent or path-consistent with the previous clip. A similarity judgment task was administered; participants decided how similar the new clip was to the previous one. The results revealed that the language used to encode motion events had an effect on participants' event classification. Bilinguals when tested in Spanish classified events according to path of the motion more, compared to when they were tested in English, therefore showing a Thinking-for-Speaking effect. Late bilinguals relied more on path information to classify events when tested in Spanish compared to English, however early bilinguals had a path preference regardless of the language. Path preference regardless of language exhibited by early bilinguals was explained by the fact that path of the motion is the 'core schema' for motion (Talmy, 1985). 
Overall, studies investigating bilingual motion event conceptualization in adults show that there are bidirectional effects of L1 and L2 which may further differ depending on timing of L2 acquisition, that is, whether the individual is early or late bilingual. In this respect, the proposed study in comparing L1 and L2 narratives and event conceptualization patterns both within and between subjects, will contribute to the current literature where, to our knowledge, Turkish-English bilingual studies are non-existent.

\subsubsection{Encoding of motion events in Turkish and English}

Languages have different means to encode spatial information and fall into two main categories according to how motion events are encoded lexically and syntactically (Talmy, 1985). According to this categorization, English and Turkish fall into two distinct categories. English is a satellite-framed language (e.g. English, German and Russian), which conflates motion with manner expressed in the main verb (e.g. roll) and path in a non-verbal element, namely a "satellite" (e.g. roll in). In contrast, Turkish is a verb-framed language (e.g. Japanese, Spanish, Turkish and Semitic languages) which conflates motion with path in the main verb (e.g. in 'descend') and expresses manner in a subordinated verb (e.g. koş 'run') therefore using two verbal clauses to represent the motion event (e.g., adam koşarak tepeden indi 'the man descended the hill while running'; Allen et al. 2007). When speakers of English and Turkish have to encode manner and path of motion, differences arise. In English path is encoded in a verb particle but not in the verb, so the verb is free to encode manner; therefore, an English speaker can encode both path and manner in one-verbal clause; where manner is encoded in the main verb and path in the satellite. On the other hand, for Turkish, since the main verb is allocated to encode path, manner is encoded as subordinated to the main verb. As a result, Turkish speakers have to use two clauses to express both manner and path of the motion event.

Özçalışkan and Slobin (1999) compared cross-linguistic narrations of the wordless picture book Frog, where are you? by children aged between 3-to-9 and adults in three languages including Turkish, Spanish and English. The results showed that at all ages Turkish speakers used more path verbs compared to English speakers whereas English speakers used more manner verbs. When they analyzed the diversity of manner and path verbs, it was found that the lexicon of manner verbs used by English speakers was more diverse for manner verbs than for path verbs compared to Turkish and Spanish speakers, confirming the expectations. The pattern was the reverse for path verbs; English speakers used less diverse lexicon of path verbs compared to Turkish and Spanish speakers.

The important issue is the extent to which children acquiring different languages use universal mappings of semantic elements on syntactic structures and the extent to which they show effects of language-specific patterns. Bowerman's (1982) linguistic approach to universals hypothesis proposes that children across languages have similar syntactic preferences in their early utterances (Bowerman \& Levinson, 2001). According to her approach, children initially go through a stage where they map each semantic element onto a different lexical element. In the course of development, they follow languagespecific ways in encoding semantic elements onto syntactic structures.

In order to investigate the extent to which children go through universal and language-specific patterns in encoding motion events, Allen et al. (2007) tested English, Japanese and Turkish speaking children and adults. In their study, participants were shown short animated clips and asked to narrate them. The video clips were motion events in which both Manner and Path were salient and therefore would elicit both elements to be encoded as much as possible. Three-year-old children were included in the study due to the fact that at that age children do not have advanced syntax to express path and manner in one utterance. Allen et al. had two predictions: One is that children may show universal linguistic patterns at the age of 3 and therefore across three languages they may share a particular way of mapping semantic elements on syntactic structures which might differ from adult patterns. The other possibility is that children at the age of 3 might be sensitive to language-specific conceptualization and do not show 
universal pattern. In the second case, English-speaking children were expected to use one-clause constructions (Manner verb + satellite) and Turkish and Japanese children to use two-clause constructions (Manner verb + Path verb). The results revealed the use of three types of expressions in order to convey manner and path. The first one is tight packaging which refers to expressing path and manner in mono-clausal sentences (Yeşil adam tik tik tik döndü etrafında ağacın, 'green man turned tik tik tik around the tree'); the second one is semi-tight packaging which refers to expressing path in the verb but manner in a subordinated form (Domates adam yuvarlanarak yokuşu indi, 'Tomato man descended the hill rolling'), and the third one is loose-packaging which refers to expressing manner and path in two separate sentences; resulting in manner only or path only sentences. (And red guy twirled, 'kırmızı adam kıvrıldı'-manner-only, Sonra yukarı çıktı, 'Then went up'- path-only) (for examples see Allen et al. 2007, pp. 30-31). The results were analyzed based on the percentages of the three categories of packaging the participants used. The results showed that 3-year-old English-speaking children used tight-packaging more often than their Turkish-speaking peers. Turkish-speaking children used semitight packaging more often than English-speaking children, a cross-linguistic difference which is also observed in adult participants. However, when Turkish speaking adults and children were compared, it was seen that children preferred to use tight-packaging significantly more often than adults. The results were discussed to be in line with Slobin's (1985) cognitive prerequisites hypothesis, which proposes that children do not only acquire the structures provided by their language but also this acquisition is accompanied with universal perceptual and cognitive categories. Later, grammatical forms are mapped on to these cognitive categories. More specifically, the authors pointed out that the language specific patterns had not yet been consolidated by age 3, contrary to claims in the literature, and that some remnants of universal tendencies for "compact syntactic constructions such as packaging both elements in one clause rather than two" were still observed (Allen et al, 2007, p. 45).

The present study which aims to investigate motion event conceptualization in bilingual children is important in a number of respects. First, if evidence shows that there is an effect of L2 on L1 while speaking L1 (as well as an effect of L1 on L2), this would suggest that acquiring L2 at an early age has an effect on children's motion event conceptualization and provide stronger evidence for the Thinkingfor-Speaking account. Second, Turkish and English have been studied cross-linguistically comparing monolingual subjects, not bilingual, and to our knowledge, there is no study investigating the effects of these two typologically different languages on the bilingual mind at the preschool level. The present study compared the event lexicalization patterns of L1: Turkish and L2: English bilingual and L1: Turkish monolingual children. The specific hypotheses are as follows:

(1) If L2: English exposure influences L1: Turkish, then five-year-old bilinguals will use more manner structures in L1 narrative motion scenes compared to 5-year-old monolinguals.

(2) Seven-year-old bilinguals will not differ in the use of manner structures in L1 narrative motion scenes compared to 7-year-old monolinguals.

(3) Bilingual children will display more manner structures in their L2 narrative motion scenes compared to their L1 narrative motion scenes.

\subsection{Research questions}

We asked two research questions:

(1) Does learning a second language early in childhood has an effect on children's motion event conceptualization reflected in their lexicalizations in their first language and

(2) Are the effects bidirectional in the sense that L2 influences L1 lexicalizations and L1 influences L2 lexicalizations 


\section{Method}

\subsection{Sample / Participants}

One hundred and twelve 5- and 7-year-old ( $\mathrm{N}=54, \mathrm{M}_{\mathrm{age}}=69$ months $\mathrm{SD}=3.76$ and $\mathrm{N}=58, \mathrm{M}_{\mathrm{age}}=91$ months, $\mathrm{SD}=4.33$, respectively) bilingual and monolingual children participated in the study. Sixty-one monolingual ( 34 females) and 51 bilingual children ( 25 females) were tested. All children were from L1: Turkish families, having native Turkish-speaking mothers and fathers. Both 5- and 7-year-old bilinguals have attended an English-immersion preschool for three years between the ages of 3;0 and $5 ; 11$. The 5-year-old group consisted of children who were tested at the end of their third year in the preschool while the 7-year-old group consisted of children who, after completing the same preschool, attended a Turkish-dominant primary school for two years and were tested at the end of the second grade. By testing 5-year-old bilinguals at the end of three school years in the English immersion school, we were able to explore the effects of intense exposure to English on children's motion event descriptions in Turkish and English. By testing 7-year-old bilinguals, we were able to investigate the effects of two-year Turkish dominant schooling on children's event descriptions in their two languages. All families were of middle-to-high socio-economic standing and mother's level of education between the two groups did not differ, $t(110)=-1.64, p=.103$.

\subsection{Instruments}

\subsubsection{Language Competence Tasks}

Receptive vocabulary was taken as an index of children's language competence for both L1: Turkish and L2: English. For L1, Turkish Expressive and Receptive Language Test (TİFALDİ) - Receptive subtest (Berument \& Güven, 2012) was administered to both bilingual and monolingual children. This is a norm-referenced vocabulary test that consists of 159 items targeting the 2 to 12 years of age range. For each item, the child is presented a word and shown a page with four pictures and her task is to select the picture that best illustrates that word's meaning.

The Peabody Picture Vocabulary Test-4 (PPVT-4), (Dunn \& Dunn, 2012) was administered to bilingual children. This is a norm referenced instrument for measuring receptive vocabulary of children and adults. PPVT-4 consists of 228 test items consisting of four full-color pictures as response options on a page. As in TIFALDİ, the child is presented a word and shown a page with four pictures to choose the correct response from.

\subsubsection{Narrative skills Tasks}

A wordless picture book (Frog, where are you? Mayer, 1969) was presented to the child. The experimenter made sure that neither the experimenter nor the child knows about the book until the child tells the story. This was assured by placing identical books in two different colored envelopes and asking the child to choose one of them. The experimenter acted as if she saw the book for the first time. Participants were asked to go over the pages to comprehend the story and were asked to tell the story to the experimenter. All sessions were videotaped and transcribed for analyses. Both bilingual and monolingual children performed the task in L1: Turkish. Bilingual children performed the same task in English on a different day implemented by an English-speaking experimenter.

\subsection{Data collection and analysis}

All children were tested close to the end of the school year so that there were three school years of L2 immersion for 5-year-old bilinguals and two school years of L1 immersion for 7-year-old bilinguals. All children were tested in the school setting in a quiet room. Turkish sessions were always performed 
first. Following the completion of Turkish sessions within maximum two weeks, English sessions were administered. Turkish sessions were performed by the researcher in the designated order: (1) Narrative skills task and (2) TIFALDİ. English sessions were administered only to the bilingual group in the following order: (1) Narrative skills task and (2) PPVT-4. The English sessions were undertaken by three research assistants in order to prevent language bias of the participants.

All Turkish and English stories were transcribed and for all six scenes all path and manner constructions used to describe the motion events were coded. In Turkish, for manner expressions we coded: Manner as a verb (e.g., zipliyor, is jumping), Manner as an adverbial clause (e.g., ziplayarak gitti, went running), and Manner as an adverb (e.g., hizlıca gidiyor, going fast). For path information we coded Path as a verb (e.g., çılkyor, is exiting), Path as a light verb (e.g., geliyor, is coming), Path as a postposition (e.g., arkasından geliyor, coming behind) and Path as a suffix (e.g., bahçe-ye atlyyor, is jumping to the garden). For English expressions, we coded: Manner as a verb (e.g., skipping), Manner as an adverb (e.g., walking fast) for manner structures. For path information we coded Path as a verb (e.g., entering), Path as a light verb (e.g., going), Path as a preposition (e.g., running up the stairs). We did not code Manner as adverbial clause and Path as suffix for English as the former did not appear in the data and the latter is not relevant for English.

Depending on how manner and path structures were used in English and Turkish descriptions, three main response categories were formed. Manner-only descriptions included any manner of motion as listed above, but not path information (e.g., atllyor, is jumping, hızlı koşuyor, running fast), Path-only descriptions involved only path structures as listed above but neither of the manner information (e.g., çıkıyor, is exiting, yukarı çıkıyor, going up), Path-and-Manner descriptions included both path and manner components (e.g., seke seke giriyor, enters skipping).

For each of the above structures, coding was undertaken by the researcher and for reliability purposes one trained undergraduate student of psychology took part in coding as well. Inter-rater reliability for Manner and Path structures were measured both by percent agreement as well as by kappa. Percent agreement for Manner structures and Path structures were .92 and .93 , respectively. There was a high agreement between the raters for Manner $(\kappa=.87(95 \%$ CI, .82 to .94$), p<.01)$ and Path structures ( $\kappa$ $=.90(95 \% \mathrm{CI}, .88$ to .95$), p<.01)$. All disagreements were resolved until an agreement was reached.

\section{Results}

\subsection{Expressing path and manner in L1 frog story narratives}

\subsubsection{Manner-only, path-only and path-and-manner descriptions in L1 Frog Story Narratives}

In order to test first and second hypotheses, we investigated whether there are effects of language group (bilingual vs. monolingual) on children's descriptions of motion scenes. The analyses were performed by taking percentages of Manner-only, Path-only, and Path-and-Manner (See Table 1) categories as dependent variables. 2 (Age: 5-and 7-year-olds) x 2 (Language group: monolingual and bilingual) factorial ANOVAs were conducted.

For Manner-only descriptions, there was a main effect of language group, $(F(1,107)=17.16, p<$ $\left..001, \eta_{p}{ }^{2}=.14\right)$, bilinguals $(\mathrm{M}=.42, \mathrm{SD}=.28)$ produced more Manner-only utterances compared to monolinguals $(\mathrm{M}=.23, \mathrm{SD}=.21)$. There was no significant effect of age $\left(F(1,107)=.02, p=.878 \eta_{p}^{2}\right.$ $=0)$, however there was a significant interaction of age $\mathrm{x}$ language group $\left(F(1,107)=4.89, p<.05 \eta_{p}{ }^{2}\right.$ $=.05)$. Post hoc $\mathrm{t}$-tests showed $(t(49)=-4.19, p<.001)$ that 5 -year-old bilinguals $(\mathrm{M}=.48, \mathrm{SD}=.29)$ produced more Manner-only utterances compared to 5-year-old monolinguals $(\mathrm{M}=.18, \mathrm{SD}=.24)$, however for 7-year-olds no such difference was found $(t(56)=-1.66, p=.101)$. 
Table 1. Mean Percentages and Standard Deviations for Path-only, Manner-only and Path-and-Manner Descriptions by Language and Age Group for L1 and L2 Narratives

\begin{tabular}{|c|c|c|c|c|c|c|c|c|c|c|c|c|}
\hline & \multicolumn{4}{|c|}{ monolinguals } & \multicolumn{4}{|c|}{ bilinguals - L1 } & \multicolumn{4}{|c|}{ bilinguals - L2 } \\
\hline & \multicolumn{2}{|c|}{ 5-year-olds } & \multicolumn{2}{|c|}{ 7-year-olds } & \multicolumn{2}{|c|}{ 5-year-olds } & \multicolumn{2}{|c|}{ 7-year-olds } & \multicolumn{2}{|c|}{ 5-year-olds } & \multicolumn{2}{|c|}{ 7-year-olds } \\
\hline & M & SD & $\mathrm{M}$ & SD & M & $\mathrm{SD}$ & M & SD & M & SD & M & SD \\
\hline Manner-only & .18 & .24 & .29 & .21 & .48 & .29 & .38 & .25 & .31 & .20 & .23 & .25 \\
\hline Path-only & .61 & .21 & .53 & .23 & .30 & .23 & .46 & .29 & .55 & .28 & .70 & .24 \\
\hline Path-and-Manner & .21 & .18 & .18 & .19 & .22 & .23 & .16 & .17 & .13 & .26 & .06 & .13 \\
\hline $\mathrm{N}$ & \multicolumn{2}{|c|}{27} & \multicolumn{2}{|c|}{33} & \multicolumn{2}{|c|}{26} & \multicolumn{2}{|c|}{25} & \multicolumn{2}{|c|}{26} & \multicolumn{2}{|c|}{22} \\
\hline
\end{tabular}

For Path-only utterances, there was a main effect of language group, $F(1,107)=16.07, p<.001 \eta_{p}{ }^{2}$ $=.13$, where monolinguals $(\mathrm{M}=.56, \mathrm{SD}=.22)$ produced more Path-only utterances compared to bilinguals $(\mathrm{M}=.38, \mathrm{SD}=.27)$. There was no significant effect of age $\left(F(1,107)=.809, p=.37 \eta_{p}^{2}\right.$ $=.008)$, however a significant interaction of age $\mathrm{x}$ language group was found $(F(1,107)=6.29, p<.05$ $\left.\eta_{p}{ }^{2}=.06\right)$. Post-hoc tests showed that the difference came from 5 -year-olds where bilinguals $(\mathrm{M}=.30$, $\mathrm{SD}=.23)$ produce less Path-only descriptions than monolinguals $(\mathrm{M}=.61, \mathrm{SD}=.21),(t(49)=4.87, p<$ $.001)$. There was no difference for 7-year-olds when bilinguals $(\mathrm{M}=.46, \mathrm{SD}=.29)$ and monolinguals $(\mathrm{M}=.53, \mathrm{SD}=.23)$ were compared $(t(56)=1.02, p=.309)$.

Same analyses were carried out for Path-and-Manner descriptions, where path and manner structures are both used in one utterance. The results showed that there was no effect of language group $\left(F(1,107)=.039, p=.843 \eta_{p}{ }^{2}=0\right)$, both bilinguals $(\mathrm{M}=.19, \mathrm{SD}=.20)$ and monolinguals $(\mathrm{M}=.20, \mathrm{SD}$ $=.19)$ were equally likely to produce Path-and-Manner descriptions. There was also no significant effect of age $\left(F(1,107)=1.67, p=.199 \eta_{p}{ }^{2}=.02\right)$ and no interaction effect $\left(F(1,107)=.118, p=.732 \eta_{p}{ }^{2}=.001\right)$. (See Figure 1)

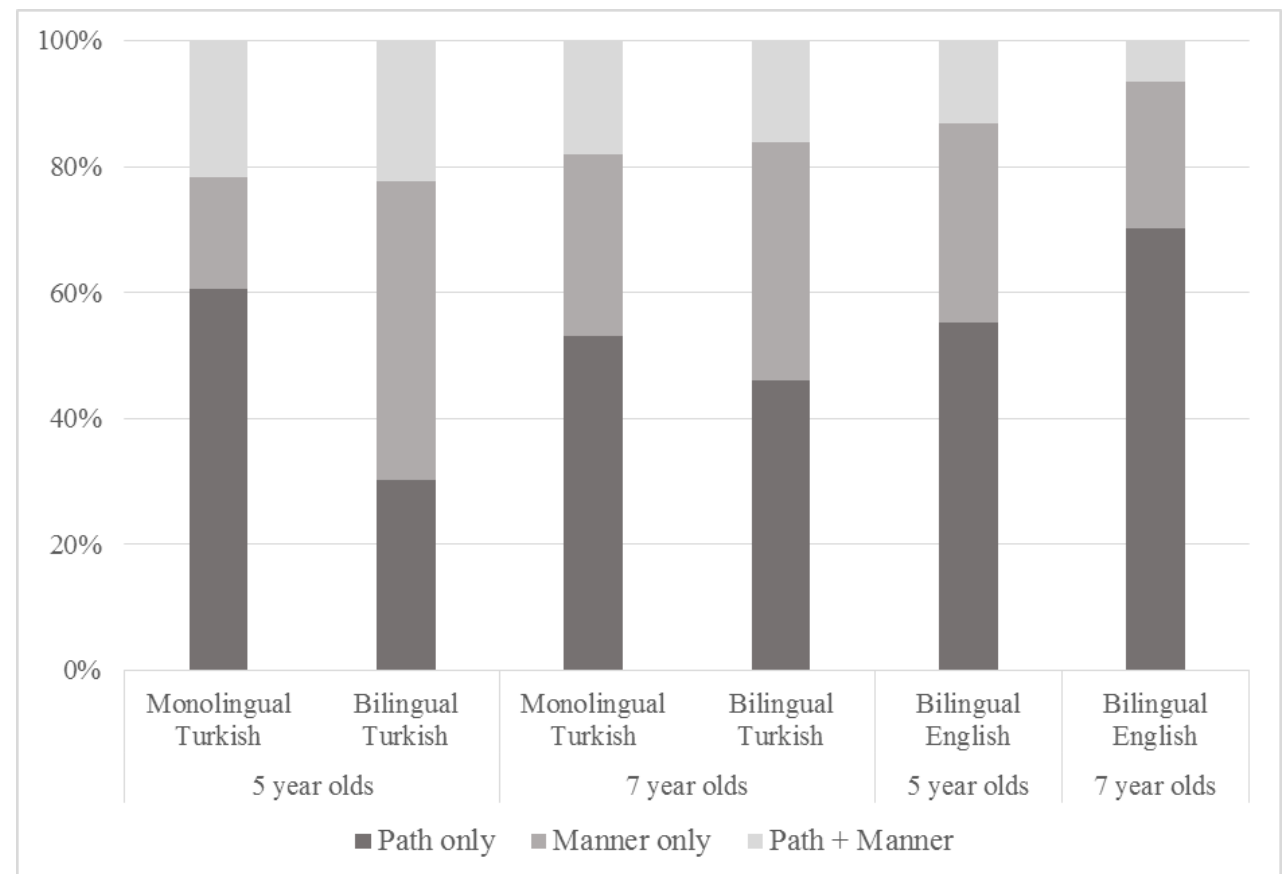

Figure 1. Mean percentages for path-only, manner-only and path-and-manner descriptions by language and age group for L1 and L2 narratives 


\subsubsection{Manner verbs and path verbs in L1 frog story narratives}

In order to investigate differences between bilinguals and monolinguals in greater detail we analyzed manner and path verbs separately. For this purpose, all of the motion verbs used in the selected 6 scenes from Frog story were categorized as Manner verbs or Path verbs. If the child has described more than one motion event for the selected scenes, then the coding was applied to all motion events described (such instances were very rare). Percentage of Manner and Path verbs added up to hundred. Mean percentages and standard deviations of Manner and Path verbs can be seen in Table 2.

Table 2. Mean Percentages and Standard Deviations for Manner and Path Verbs by Language and Age Group for L1 and L2 Narratives

\begin{tabular}{|c|c|c|c|c|c|c|c|c|c|c|c|c|}
\hline & \multicolumn{4}{|c|}{ monolinguals } & \multicolumn{4}{|c|}{ bilinguals - L1 } & \multicolumn{4}{|c|}{ bilinguals - L2 } \\
\hline & \multicolumn{2}{|c|}{ 5-year-olds } & \multicolumn{2}{|c|}{ 7-year-olds } & \multicolumn{2}{|c|}{ 5-year-olds } & \multicolumn{2}{|c|}{ 7-year-olds } & \multicolumn{2}{|c|}{ 5-year-olds } & \multicolumn{2}{|c|}{ 7-year-olds } \\
\hline & M & SD & $\mathrm{M}$ & SD & M & SD & M & SD & M & SD & $\mathrm{M}$ & SD \\
\hline Manner verbs & .37 & .24 & .45 & .24 & .77 & .25 & .57 & .29 & .53 & .29 & .36 & .24 \\
\hline Path verbs & .63 & .24 & .55 & .24 & .23 & .25 & .43 & .29 & .47 & .29 & .64 & .24 \\
\hline $\mathrm{N}$ & \multicolumn{2}{|c|}{26} & \multicolumn{2}{|c|}{33} & \multicolumn{2}{|c|}{26} & \multicolumn{2}{|c|}{25} & \multicolumn{2}{|c|}{26} & \multicolumn{2}{|c|}{22} \\
\hline
\end{tabular}

We again conducted 2 (Age: 5-and 7-year-olds) x 2 (Language group: monolingual and bilingual) factorial ANOVA. For Manner verbs, there was a significant effect of language group, $F(1,107)=27.14$, $p<.001 \eta_{p}{ }^{2}=.21$, where bilinguals $(\mathrm{M}=.67, \mathrm{SD}=.29)$ expressed more Manner verbs compared to monolinguals $(\mathrm{M}=.42, \mathrm{SD}=.24)$. There was no main effect of age, $F(1,107)=1.36, p=.245 \eta_{p}{ }^{2}=.01$, where 5-year-olds $(\mathrm{M}=.56, \mathrm{SD}=.31)$ and 7-year-olds $(\mathrm{M}=.50, \mathrm{SD}=.27)$ used Manner verbs equally likely. There was a significant interaction of age $\mathrm{x}$ language group, $F(1,107)=7.97, p<.01 \eta_{p}{ }^{2}=.07$. Post hoc t-test showed that bilingual 5-year-olds expressed $(\mathrm{M}=.77, \mathrm{SD}=.25)$ more manner verbs compared to their monolingual peers $(\mathrm{M}=.37, \mathrm{SD}=.24), t(49)=-5.82, p<.001$. There was no significant difference between monolingual 7-year-olds $(\mathrm{M}=.29, \mathrm{SD}=.21)$ and bilingual 7-year-olds $(\mathrm{M}=.38, \mathrm{SD}=.25), t(56)=-1.67, p=.234$. Complementary results were obtained for Path-verbs. Again there was significant main effect of language group $F(1,107)=27.14, p<.001 \eta_{p}{ }^{2}=.21$, where monolinguals $(\mathrm{M}=.58, \mathrm{SD}=.24)$ expressed more Path verbs than bilinguals $(\mathrm{M}=.33, \mathrm{SD}=.29)$. Again there was no significant age effect, $F(1,107)=1.36, p=.245 \eta_{p}{ }^{2}=.01$ but a significant interaction effect of age $\mathrm{x}$ language group, $F(1,107)=7.97, p<.01 \eta_{p}{ }^{2}=.07$. Post hoc t-test showed that among 5-yearolds $(\mathrm{M}=.63, \mathrm{SD}=.24)$, monolinguals used more Path verbs compared to bilingual peers $(\mathrm{M}=.23, \mathrm{SD}$ $=.25), t(49)=5.82, p<.001$. There was no difference among 7-year-olds in the usage of Path verbs when bilinguals $(\mathrm{M}=.43, \mathrm{SD}=.29)$ and monolinguals $(\mathrm{M}=.55, \mathrm{SD}=.25)$ were compared, $t(56)=$ $1.67, p=.101$.

\subsection{Expressing path and manner in L1 vs. L2 frog story narratives of bilinguals}

In order to test the third hypothesis, we compared L1 and L2 narratives of bilingual children. For bilingual group we compared L1 and L2 Frog Story narratives based on the categories of Manner-only, Path-only and Path-and-Manner separately. For this purpose, we performed 2x2 (language: L1-L2 x age group) Mixed ANOVA's. For post-hoc tests that were performed for significant interactions we utilized Bonferroni adjusted alpha level .017.

3.2.1. Manner-only, path-only and path-and-manner descriptions in L1 vs. L2 frog story narratives of bilinguals

For Manner-only descriptions, there was a main effect of language, $F(1,44)=6.35, p<.05, \eta_{p}{ }^{2}=$ .137. Bilingual children used more Manner-only descriptions in their L1 $(\mathrm{M}=.41, \mathrm{SD}=.26)$ narratives 
compared to their $\mathrm{L} 2(\mathrm{M}=.27, \mathrm{SD}=.23)$ narratives. There was no main effect of age or age $\mathrm{x}$ language interaction, $\left(F(1,44)=2.54, p=.119, \eta_{p}{ }^{2}=.06, F(1,44)=.001, p=.982, \eta_{p}{ }^{2}=0\right.$, respectively $)$.

For Path-only descriptions, there was a main effect of language, $F(1,44)=16.67, p<.001, \eta_{p}{ }^{2}=$ .294. Bilingual children used less Path-only descriptions in their L1 $(\mathrm{M}=.38, \mathrm{SD}=.27)$ narratives compared to their $\mathrm{L} 2(\mathrm{M}=.63, \mathrm{SD}=.27)$ narratives. There was a main effect of age, where 7-year-olds $(\mathrm{M}=58, \mathrm{SD}=.25)$ used more Path-only descriptions compared to 5-year-olds $(\mathrm{M}=.42, \mathrm{SD}=.28)$ $F(1,44)=8.29, p<.01, \eta_{p}{ }^{2}=.172$. There was no significant interaction of age and language, $F(1,44)=$ $.014, p=.906, \eta_{p}{ }^{2}=0$.

For Path-and-Manner descriptions, there was a main effect of language, where bilingual children used more Path-and-Manner descriptions in their L1 narratives $(\mathrm{M}=.21, \mathrm{SD}=.20)$ compared to their L2 narratives $(\mathrm{M}=.09, \mathrm{SD}=.20), F(1,44)=5.97, p<.05, \eta_{p}{ }^{2}=.130$. There was no main effect of age or age $\mathrm{x}$ language interaction, $\left(F(1,44)=3.33, p=.075, \eta_{p}{ }^{2}=.077, F(1,44)=.036, p=.850, \eta_{p}{ }^{2}=\right.$ .001 , respectively)

\subsubsection{Manner verbs and path verbs in L1 vs. L2 frog story narratives of bilinguals}

For Manner verbs there was a main effect of language, where bilingual children used more Manner verbs in their $\mathrm{L} 1$ narratives $(\mathrm{M}=.67, \mathrm{SD}=.30)$ compared to their $\mathrm{L} 2$ narratives $(\mathrm{M}=.44, \mathrm{SD}=.27)$, $F(1,44)=13.45, p<.001, \eta_{p}{ }^{2}=.267$. There was also a significant effect of age, where 5-year-olds (M $=.66, \mathrm{SD}=.24)$ used more Manner verbs compared to 7-year-olds $(\mathrm{M}=.48, \mathrm{SD}=.31)$. There was no significant interaction of age $\mathrm{x}$ language, $F(1,44)=.178, p=.675, \eta_{p}^{2}=.005$.

We obtained similar complementary results for Path verbs. There was again main effect of language on scores, where bilingual children used more Path verbs in their $\mathrm{L} 2$ narratives $(\mathrm{M}=.56, \mathrm{SD}=.27)$ compared to their $\mathrm{L} 1$ narratives $(\mathrm{M}=.33, \mathrm{SD}=.30), F(1,44)=13.45, p<.001, \eta_{p}{ }^{2}=.267$. There was also a significant effect of age, where 7-year-olds $(\mathrm{M}=.52, \mathrm{SD}=.31)$ used more Path verbs compared to 5 -year-olds $(\mathrm{M}=.34, \mathrm{SD}=.24)$. There was no significant interaction of age $\mathrm{x}$ language, $F(1,44)=$ $.178, p=.675, \eta_{p}{ }^{2}=.005$. List of all manner and path verbs used L1 and L2 frog story narratives can be seen in Table 3 .

Table 3. Types and (Tokens) of Manner and Path Verbs Used by Monolingual and Bilingual Children in L1 and L2 Narratives

\begin{tabular}{l|l|l}
\hline \multicolumn{2}{c}{ Manner verbs } \\
\hline Monolinguals-L1 (8 types) & Bilinguals-L1 (13 types) & Bilinguals-L2 (10 types) \\
\hline at 'throw'(13) & at 'throw'(32) & throw (3) \\
atla 'jump'(6) & atla 'jump'(25) & jump (14) \\
kaç 'run away'(29) & koş 'run' (18) & escape (5) \\
bat 'sink'(11) & bas 'step'(3) & climb (6) \\
kovala 'chase' (3) & kovala 'chase'(5) & chase (4) \\
uç 'fly'(3) & uç 'fly'(1) & pun (7) \\
yuvarlan 'roll' (2) \\
zıpla 'bounce' (2)
\end{tabular}




\begin{tabular}{l|l|l}
\hline \multicolumn{2}{c}{ Path verbs } \\
\hline Monolinguals-L1 (4 types) & Bilinguals-L1 (2 types) & Bilinguals-L2 (1 type) \\
\hline $\begin{array}{l}\text { çı 'exit' (64) } \\
\text { düş 'fall' (90) } \\
\text { gir 'enter (2) } \\
\text { in 'descend' (3) }\end{array}$ & gir 'enter' (2) & fall (78) \\
\hline
\end{tabular}

\subsection{Language Competence Tasks}

\subsubsection{Turkish expressive and receptive vocabulary test - receptive subtest TIFALDI-R}

We conducted a 2 (Age: 5-and 7-year-olds) x 2 (language group: monolingual and bilingual) factorial ANOVA. The results showed that there was no main effect of language group on vocabulary, $F(1,108)$ $=.406, p=.525, \eta_{p}{ }^{2}=.004$, monolinguals $(\mathrm{M}=81.67, \mathrm{SD}=.11 .70)$ and bilinguals $(\mathrm{M}=79.84, \mathrm{SD}=$ $11.59)$ performed similarly. There was significant age effect, $F(1,108)=91.10, p<.001, \eta_{p}{ }^{2}=.46$, where 7-year-olds $\left(\mathrm{M}=88.41, \mathrm{SD}=5.01\right.$; corresponding to $8 ; 09$ age level and $71^{\text {st }}$ percentile for monolingual Turkish-speaking children) performed better than 5-year-olds $(\mathrm{M}=72.70, \mathrm{SD}=11.25$; corresponding to $6 ; 11$ age level and $66^{\text {th }}$ percentile for monolingual Turkish-speaking children). There was no interaction effect of age $\mathrm{x}$ language group, $F(1,108)=.104, p=.747, \eta_{p}{ }^{2}=.001$.

\subsubsection{Peabody picture vocabulary test - 4 (PPVT-4)}

Due to the fact that the PVVT was administered only to the bilingual group, we only made comparisons within the bilingual participants. We compared 5-year-old bilinguals and 7-year-old bilinguals by conducting independent samples t-test. The results showed that 7-year-olds $(M=99.56$, $\mathrm{SD}=22.66$ ), (corresponding to $6 ; 1$ age level and $28^{\text {th }}$ percentile for monolingual English-speaking children) performed better than 5-year-olds $(\mathrm{M}=72.54, \mathrm{SD}=20.12)$ (corresponding to 4;2 age level and $16^{\text {th }}$ percentile for monolingual English-speaking children) (See Table 4).

Table 4. Means and Standard Deviations for TİFALDİ-R and PPVT-4 Scores by Language and Age Group

\begin{tabular}{lclllllll}
\hline & \multicolumn{1}{c}{ monolingual } & \multicolumn{5}{c}{ bilingual } \\
\hline & 5-year olds & \multicolumn{2}{c}{ 7-year olds } & 5-year olds & 7-year olds \\
\hline & M & SD & M & SD & M & SD & M & SD \\
TíFALDİ-R & 73.46 & 11.78 & 88.64 & 5.54 & 71.88 & 10.81 & 88.12 & 4.29 \\
PPVT-4 & - & - & - & - & 72.54 & 20.12 & 99.56 & 22.66 \\
\hline
\end{tabular}

\section{Discussion}

The present study aimed to answer two major research questions (1) Does learning a second language early in childhood has an effect on children's motion event conceptualization reflected in their lexicalizations in their first language and (2) Are the effects were bidirectional in the sense that L2 influences L1 lexicalizations and L1 influences L2 lexicalizations? These questions were investigated by comparing narratives produced in both L1 and L2 by bilingual children to those produced by monolingual children. In addition, executive functioning and vocabulary assessments were made for both groups of children. 
Following Slobin's Thinking-for-Speaking hypothesis, we examined motion event conceptualization comparing young Turkish monolingual and bilingual children's motion event descriptions produced in narratives. Studying children learning Turkish (V-framed) and English (S-framed) languages that fall into different categories in terms of the expression of motion provide an opportunity to investigate the effects of learning a second language on motion event conceptualization in bilingual vs. monolingual minds. Overall, findings indicate bidirectional effects between L1 and L2. Findings are discussed in the light of the Thinking-for-Speaking framework considering the hypotheses of the study.

It was hypothesized that 5-year-old bilingual children would use more manner structures and less path structures in their L1 narratives compared to their monolingual peers but that there would be no such difference for 7-year-olds. These hypotheses were confirmed. The results showed that 5 -year-old bilingual children used more manner structures in the forms of manner verbs in their L1 narratives. They also used more Manner-only constructions and less Path-only expressions. For 7-year-old bilinguals, there was no difference from monolinguals as expected. These findings are explained by the amount of exposure the different age groups had to their two languages. Five-year-olds were in an L2 immersion environment for three preschool years. In addition, they were tested in their preschool setting where teachers and other staff always speak English. Therefore, it can be argued that they have been primed to talk and think in English when they participated in the data collection sessions of the study. On the other hand, 7-year old bilinguals who started primary school at 6-years of age were exposed to an L1 curriculum and the amount of L2 exposure decreased to about one fourth the hours of L2 in preschool. Thus, with the advance of literacy, the context of L1 usage was enriched and gained momentum compared to L2 activities.

These findings are in line with previous research investigating the effects of L2 on L1 motion conceptualization in adult bilinguals (Cadierno \& Ruiz, 2006, Hohenstein et al., 2006; Filipovic, 2011) as well as children. In a study comparing L1: Spanish, L2: English bilingual children with Spanish monolinguals, Aveledo (2015) had children of three age groups (5 to 6, 7 to 9 and 10 to 12 years of age) watch and describe naturalistic videos depicting different manner and path combinations. Results showed that bilinguals produced more manner verbs and fewer path verbs than monolinguals in their L1 Spanish. However, the results differed for different age groups; 5- to 6-year-old bilinguals performed closer to Spanish than English, whereas 7- to 9-year olds showed a considerable increase in manner verb production, explained in terms of an influence of L2-English on L1 Spanish. Differences in the amount of exposure to L2-English for different age groups also accounted for the findings. Five- to 6-year-olds were exposed to 8 hours/week of English classes whereas this amount was 16 hours/week for 7-to-9year-olds. In a further study Aveledo and Athanasopoulos (2016) replicated Aveledo (2015) and got the same results. The findings of both studies converge with the findings of the present study as they show that more L2 hours in school enhances the likelihood of L2 effects on children's motion descriptions in L1. In a study comparing L1-Turkish - L2-English bilingual, Turkish monolingual, and English monolingual adult participants, Özçalışkan (2016) showed that in describing events in Turkish, TurkishEnglish bilinguals used fewer conflated (path and manner described in a single clause) but more separated (path and manner expressed in more than one clause) constructions than English monolinguals, but they did not differ from Turkish monolinguals, producing similar amounts of separated and conflated descriptions. These findings with adults indicating no monolingual-bilingual difference in use of path and manner constructions are similar to our findings of no monolingualbilingual difference for 7-year-olds. However, they differ from our findings for 5-year old bilinguals who used more manner constructions than monolinguals. This lack of difference between bilingual vs. monolingual adults in Özçalışkan's study can be explained by the late AoO of L2 (M=11.8 years), which is much later than $\mathrm{AoO}$ of $\mathrm{L} 2$ in the present study ( $\mathrm{M}=3.0$ years). 
The AoO of L2 immersion for bilingual children of the present study was around the age 3 . Allen et al. (2007) found that language specific patterns had not yet been consolidated by age 3 , and that some remnants of universal tendencies for "compact syntactic constructions such as packaging both elements in one clause rather than two" were still observed (Allen et al, 2007, p. 45). The results of the present study showing effects of L2 on motion event descriptions of bilingual 5-year-olds in L1 may also be interpreted as reflecting the consequences of early L2 immersion that starts before language-specific patterns have been consolidated. The finding of no difference for 7-year-olds is informative about the timing and duration of L2 immersion. When L2 immersion was replaced by L1 dominance in formal schooling at the age of 6 , the effects of L2 on L1 were overwritten.

Differences in L1 frog story motion scenes of bilinguals and monolinguals highlighted L2 influences on L1 by showing that children immersed in L2 between 3-5 years of age produced more manner constructions following the L2-English pattern, than monolingual age mates. On the other hand, differences in L2 descriptions frog story motion scenes of the 5- and 7- year old bilinguals highlighted L1 influences on L2 due to increased exposure to L1.

The results of the present study for comparison of L1 and L2 frog story motion scenes yielded an unexpected result for encoding of manner and path structures. Bilingual children, regardless of age group, in their L1 compared to their L2 narratives, encoded more manner verbs and fewer path verbs, more Manner-only and Path-and-Manner and fewer Path-only constructions. This finding is unexpected since Turkish as a V-framed language is more a path rather than manner language contrary to English. One explanation is that bilingual children who produced L2 narratives after they told the story in L1 skipped some of the scenes that could have yielded manner information. In fact, bilingual children, regardless of age, included less information for the plot for L2 compared to L1 tellings, and the scenes skipped most often were those where the gopher pops out of the hole, the owl flies out from its nest and the bees chase the boy, which all call for manner descriptions. A further inspection of the data showed that more than half of the motion verbs used to describe the scenes were the verb "fall" which is a path verb, and these were the scenes depicting the boy's fall. That second tellings become less detailed than the first due to an order effect is also recognized in the literature (Pavlenko, 2009). Another explanation for the unexpected result concerns the discourse level perspective bilingual children seem to have adopted in telling the story. Producing narratives in L2 is more demanding for early second language acquirers, therefore maintaining the boy's perspective as the main protagonist might have been easier for them. Such a strategy would enhance the likelihood of the use of the verb "fall" and increase the percentage of path structures. Sticking to the main protagonist's perspective - also called the thematic subject strategy (Karmiloff-Smith, 1981) - rather than shifting perspectives has been found to be a relatively less taxing way to organize the story for young children even in L1 (Aksu-Koç \& Tekdemir, 2004). An alternative explanation which argues that bilingual children may be using the verb "fall" like a light verb because they lack the necessary vocabulary for motion verbs due to limited vocabulary can be ruled out in view of the variety of manner verbs (10 types) bilingual children have used in the context of their L2 narratives. In short, the unexpected low percentage of manner verbs in L2 descriptions of narrative scenes can be argued to be a combined outcome of order effect as well as the discourse level perspective preferences.

The present study highlighted important bidirectional interactions between L1 and L2 in childhood. The comparison of L1's of monolinguals vs. bilinguals revealed an effect of L2-English on L1-Turkish (with higher percentage of manner verbs in Turkish) for 5-year-olds. The comparison of L2s of the two bilingual groups across age revealed an effect of L1-Turkish on L2-English (with higher percentage of Path-only constructions and more path verbs) for 7-year-olds than 5-year olds. The influence of L1 on L2 often called as 'transfer effects' has been investigated more often than influences of L2 on L1 (e.g., Meisel, 2004, 2007; Unsworth \& Blom, 2010). For language pairings such as Turkish and English, to 
our knowledge, this is the first study that investigates the bidirectional effects of L1-Turkish and L2English in early childhood. The two types of tasks used, the motion event conceptualization task which allows for more experimental control, and the frog story narrative which allows for more ecological validity, yielded converging evidence for bidirectional effects of L1 and L2 in the motion event conceptualization context.

Closer investigation of manner and path verbs used in both frog story narratives revealed interesting points. Bilinguals tended to use more types of manner verbs compared to monolinguals in their L1. What matters for the questions of the present study is not the number of types of the manner and path verbs that monolingual and bilingual children possess for the language used, but which ones they prefer to use at the time of speaking. Since the monolingual and bilingual children did not differ in terms of their knowledge of vocabulary in Turkish it can be safely assumed that the difference in the number of manner verb types given above reflect a difference in the preference of bilingual vs. monolinguals for ways of encoding events that determines the difference, which presents a further support for Thinking-forSpeaking.

A second point concerning verbs is that very few types of path verbs were used compared to manner verbs in frog story narratives both by bilinguals and monolinguals. While this may be a function of the scenes presented, it may also be a function of the fact that path is a core obligatory component of motion (Talmy, 1985; Slobin, 2004) and does not show as much variation as manner to be coded with a rich variety of verbs in language.

The results of the present study provide input in two respects. First, the present study has used a within subject design with a bilingual population and two different methodologies that yielded differences in motion event descriptions in the two languages. The L1 descriptions of the bilingual 5year-old participants displayed more manner constructions than monolinguals, reflecting an effect of L2, the language of their preschool context.

Overall, findings support the Thinking-for-Speaking hypothesis that when speakers are expressing their thoughts, they engage in a form of thinking that is provided by the grammatical and lexical characteristics of their language. Slobin (1987, p.435) suggests that Thinking-for-Speaking involves using those characteristics "that (a) fit some conceptualization of the event, and (b) are readily encodable in the language". Thus, it is "a special thought that is mobilized for communication" (Slobin, 1996, p.76). As the present study has shown, having acquired L2 that frames motion events differently than L1 has projections on L1. Even an early L2 user appears to conceptualize motion events in L1 through the filter of L2 while speaking. The question of whether a speaker of L1 who has acquired an L2 linguistic system has also acquired the conceptualization patterns of L2 is an important one. Pavlenko (2005) provides a number of possible outcomes for such patterns: (1) coexistence of L1 and L2 conceptual domains that suggests that bilinguals make use of distinct conceptual representations, (2) L1based conceptual transfer which refers to L1 conceptual system guiding L2 language use, in beginning and intermediate stages of L2 learning, (3) Internalization of new concepts refers to adoption of L2 words and concepts which are nonexistent in L1, (4) Shift from L1 to L2 conceptual domain, (5) Convergence of L1 and L2 conceptual domains which suggests creation of a unitary concept distinct from both L1 and L2, (6) Restructuring of a conceptual domain which refers to cases when shift is not complete and certain elements in a concept may be altered, and finally (7) Attrition of previously learned concepts which refers to loss of previously learned concepts and schemas. The results found for 5-yearold bilinguals are in line with a shift from L1 to L2 conceptual domain. In their investigation of lexicosemantic organization for bilinguals, Ameel, Storms, Malt, and Sloman (2005) suggest that due to the bidirectional effects of the two languages, early bilinguals have a merged lexico-semantic organization. This is reflected in bilinguals naming and categorization preferences compared to monolinguals which further reflects that a bilingual's category boundaries for each language seem to come closer to each 
other and differ from a monolingual's organization. Further research that incorporates both linguistic and non-linguistic measures are necessary in order to gain more insight on the issue.

To summarize, early intense exposure to L2 had meaningful consequences which are in line with the Thinking-for-Speaking hypothesis. More specifically, learning an L2 that frames motion events differently than L1 had an effect on motion event conceptualizations reflected in expressions in L1. Different patterns found for different age groups call for a broader age group of bilinguals to be investigated in future studies. Clearly, more research is needed with bilinguals for further evidence for the extent of effects that stem from early exposure. The context of L2 acquisition of the present study is one where L1 is the dominant societal language. For the sample studied L2 learning started at 3 years of age in preschool in an immersion program which ended at 6 years of age when children started primary school. Current schooling practices pose a discontinuity in L2 exposure at 6 years of age with number of hours reduced from a maximum of 40 to 10. This situation provided an opportunity for investigating the consequences of very early L2 immersion on L1. Overall, results showed that learning an L2 that is typologically different from L1 in an immersion context has noteworthy consequences on how motion events are conceptualized in a bilingual mind at the time of speaking.

\section{Conclusion}

Effects of learning a typologically different language on motion event conceptualization in early childhood have not been studied very frequently. This is the first study that investigates motion event conceptualization in children who acquire L1: Turkish and L2: English, which is one of the major contributions of the present research. In line with the Thinking-for-Speaking framework, findings revealed that early acquisition of L2 that is typologically different from L1 has influences on how motion events are conceptualized in a bilingual mind while thinking for speaking. Specifically, 5-year-old bilingual children tended to emphasize manner more than their monolingual peers. Current practices in language policies for schools enabled the investigation of the consequences of a shift from L2 immersion to L1 immersion. Data from bilingual children in both L1 and L2 enabled the investigation of bidirectional relations between their two languages.

\section{Ethics Committee Approval}

The author confirms that ethical approval was obtained from Boğaziçi University (Approval Date: 14/03/2016).

\section{References}

Allen, S., Özyürek, A., Kita, S., Brown, A., Furman, R., Ishizuka, T., \& Fujii, M. (2007). Languagespecific and universal influences in children's syntactic packaging of manner and path: A comparison of English, Japanese, and Turkish. Cognition, 102, 16-48. https://doi.org/10.1016/j.cognition.2005.12.006.

Ameel, E., Storms, G., Malt, B. C., \& Sloman, S. A. (2005). How bilinguals solve the naming problem. Journal of Memory and Language, 53(1), 60-80. https://doi.org/10.1016/j.jml.2005.02.004

Aveledo, F. E. (2015). Linguistic relativity in motion events in Spanish and English: a study on monolingual and bilingual children and adults. Unpublished Dissertation. 
Aveledo, F., \& Athanasopoulos, P. (2016). Second language influence on first language motion event encoding and categorization in Spanish-speaking children learning L2 English. International Journal of Bilingualism, 20(4), 403-420. https://doi.org/10.1177/1367006915609235

Bowerman, M. (1982). Reorganizational processes in lexical and syntactic development. Language acquisition: In E. Wanner \& L.R. Gleitman (Eds.) The state of the art, 319-46. New York: Cambridge University Press.

Bowerman, M. \& Levinson, S., (Eds.) (2001) Language acquisition and conceptual development. Cambridge: Cambridge University Press.

Brown, A., \& Gullberg, M. (2008). Bidirectional crosslinguistic influence in L1-L2 encoding of manner in speech and gesture: A study of Japanese speakers of English. Studies in Second Language Acquisition, 30(02), 225-251. https://doi.org/10.1017/S0272263108080327

Brown, A. (2015). Universal development and L1-L2 convergence in bilingual construal of manner in speech and gesture in Mandarin, Japanese, and English. The Modern Language Journal, 99(S1), 6682. doi.org/10.1111/j.1540-4781.2015. 12179

Brown, A., \& Chen, J. (2013). Construal of Manner in speech and gesture in Mandarin, English, and Japanese. Cognitive Linguistics, 24(4), 605-631. https://doi.org/10.1515/cog-2013-0021

Bylund, E. (2011). Language-specific patterns in event conceptualization: Insights from bilingualism. In A. Pavlenko (Ed.) Thinking and speaking in two languages (pp. 108-142). Bristol, UK: Multilingual Matters

Cadierno, T., \& Ruiz, L. (2006). Motion events in Spanish L2 acquisition. Annual review of cognitive linguistics, 4(1), 183-216. https://doi.org/10.1075/arcl.4.08cad

Cook, V. (Ed.). (2003). Effects of the second language on the first (Vol. 3). Clevedon, UK: Multilingual matters.

Filipović, L. (2011). Speaking and remembering in one or two languages: Bilingual vs. monolingual lexicalization and memory for motion events. International Journal of Bilingualism, 15(4), 466-485. https://doi.org/10.1177/1367006911403062

Filipović, L., and I. Vidakovic. 2010. Typology in the L2 classroom: Acquisition from a typological perspective. In Inside the Learner's Mind: Cognitive Processing in Second Language Acquisition, M. Pütz \& L. Sicola (Eds.), 269-291. Amsterdam \& Philadelphia: Benjamins

Flecken, M., Carroll, M., Weimar, K., \& Von Stutterheim, C. (2015). Driving along the road or heading for the village? Conceptual differences underlying motion event encoding in French, German, and French-German L2 users. The Modern Language Journal, 99(S1), 100-122. https://doi.org/10.1111/j.1540-4781.2015.12181.x

Hasko, V. (2010). The role of thinking for speaking in adult L2 speech: The case of (non)unidirectionality encoding by American learners of Russian. In Z-H. Han \& T. Cadierno (Eds.), Linguistic relativity in second language acquisition: Thinking-for-speaking (pp. 34-58). Clevedon, UK: Multilingual Matters.

Hohenstein, J., Eisenberg, A., \& Naigles, L. (2006). Is he floating across or crossing afloat? Crossinfluence of L1 and L2 in Spanish-English bilingual adults. Bilingualism: Language and Cognition, 9, 249-261. https://doi.org/10.1017/S1366728906002616

Karmiloff-Smith, A. (1981). A functional approach to child language: A study of determiners and reference. Cambridge: Cambridge University Press. 
Lai, V. T., Rodríguez, G. G., \& Narasimhan, B. (2014). Thinking-for-Speaking in early and late bilinguals. Bilingualism: Language and Cognition, 17(1), 139-152. https://doi.org/10.1017/S1366728913000151

Mayer, M. (1969). Frog, where are you? New York: Dial Press.

Meisel, J. M. (2004). The bilingual child. In T. K. Bhatia \& Ritchie, W. C. (Eds.), The handbook of bilingualism (pp. 91-113). Oxford: Blackwell.

Meisel, J.M. (2007). The weaker language in early child bilingualism: Acquiring a first language as a $\begin{array}{llll}\text { second language? } & \text { Applied }\end{array}$ https://doi.org/10.1017/S0142716407070270

Naigles, L. R., Eisenberg, A. R., Kako, E. T., Highter, M., \& McGraw, N. (1998). Speaking of motion: Verb use in English and Spanish. Language and cognitive processes, 13(5), 521-549. https://doi.org/10.1080/016909698386429.

Özçalışkan, Ş. (2016). Do gestures follow speech in bilinguals' description of motion? Bilingualism: Language and Cognition. 19(3), 644-653. doi:10.1017/S1366728915000796

Özçalışkan, S., \& Slobin, D. I. (1999). Learning "how to search for the frog": Expression of manner of motion in English, Spanish, and Turkish. Proceedings of the 23rd annual Boston University conference on language development, 23, 541-552. Sommerville, MA: Cascadilla Press.

Özçalışkan, Ş., \& Slobin, D. I. (2003). Codability effects on the expression of manner of motion in Turkish and English. In Studies in Turkish Linguistics. Istanbul: Boğaziçi University.

Pavlenko, A. (2009). Verbs of motion in L1 Russian of Russian-English bilinguals. Bilingualism: Language and Cognition, 13(1), 49-62. https://doi.org/10.1017/S1366728909990198

Pavlenko, A., \& Volynsky, M. (2015). Motion encoding in Russian and English: Moving beyond Talmy's typology. The Modern Language Journal, 99 (S1), 32-48. https://doi.org/10.1111/modl.12177

Slobin, D.I. (1985). Crosslinguistic evidence for the language-making capacity. In D.I. Slobin (Ed.). The crosslinguistic study of language acquisition, Vol. 2: Theoretical issues. Hillsdale, NJ: Erlbaum. Slobin, D.I.

Slobin, D. (1996). From "thought and language" to "thinking for speaking." In J. Gumperz \& S. Levinson (Eds.), Rethinking linguistic relativity (pp. 70-114). Cambridge: Cambridge University Press.

Slobin, D. I. (2004). The many ways to search for a frog: Linguistic typology and the expression of motion events. In: S. Strömqvist \& L. Verhoeven (Eds.), Relating events in narrative: Typological and contextual perspectives (pp. 219-258). Mahwah, NJ: Erlbaum.

Talmy, L. (1985). Lexicalization patterns: Semantic structure in lexical forms. Language typology and syntactic description, 3, 57-149.

Unsworth, S., \& Blom, E. (2010). Comparing L1 children, L2 children and L2 adults. In S. Unsworth, \& E. Blom (Eds.), Experimental methods in language acquisition research (pp. 313-336). Amsterdam: John Benjamins.

Wolff, P., \& Holmes, K. (2011). Linguistic relativity. Wiley Interdisciplinary Reviews: Cognitive Science, 2, 253-265. https://doi.org/10.1002/wcs.104.

Whorf, B. L. (1956). Language, thought and reality. ( J. Carroll , Ed.) . Cambridge, MA : MIT Press. 


\section{İkinci dil ediniminin hareket olayları anlatımına etkisi: İki dilli ve tek dilli çocukların karşılaştırılması}

\section{Öz}

$\mathrm{Bu}$ çalı̧̧ma çocukların anadil ve ikinci dilde hareket olaylarını nasıl anlattıklarını araştırmaktadır, Türkçe (D1: Anadil), İngilizce (D2: İkinci dil). İngilizce hareketin yapılış şeklini fiilde, hareketin yönünü ise fiil dışındaki bir yapıda kodlayan uydu-çerçeveli bir dildir. Buna karşılık Türkçe fiil-çerçeveli bir dil olup hareketin yapılış şeklini daha çok fiilimside, hareketin yönünü ise fiilde kodlamaktadır. İki temel araştırma sorusu cevaplanmaya çalışılmış̧ır: (1) Edinilen ikinci dil anadildeki hareket olay anlatımlarını etkilemekte midir? (2) Diller arası etkileşim iki yönlü müdür? Yüz on iki 5 ve 7-yaş grubu tek dilli (D1: Türkçe ve iki dilli çocuk (D1: Türkçe, D2: İngilizce) çocuk araştırmaya katılmışır. Katılımcılar Kurbağa, Neredesin? İsimli yazısız kitap için anlatılar üretmişlerdir. Kitabın içinde yer alan ve hareket olaylarını temsil eden altı sahne kodlama için seçilmiştir. Bunlar sırasıyla: (1) Kurbağanın kavanozdan kaçması, (2) Köpeğin pencereden düşmesi, (3) Tarla faresinin delikten çıkması, (4) Baykuşun ağaçtan çıkması, (5) Köpek ve çocuğun düşmesi ve (6) Çocuk ve köpeğin göle düşmesi. D1 anlatımlarında 5-yaş iki dilliler 5 yaş tek dillilere kıyasla ifadelerinde daha fazla hareketin yapılış şekline atıfta bulunup, hareketin yönü bilgisine daha az yer verirken, bu farklılık 7 yaş grubu iki dilli ve tek dilli çocuklarda gözlemlenmemiştir. İki dilli çocuklar D2 anlatımlarında D1 anlatımlarına nazaran daha az hareket şekli ve daha fazla hareket yönü içeren anlatımlar oluşturmuşlardır. Bulgular 5 yaş iki dillilerin edindikleri ikinci dil nedeniyle D1'deki anlatılarının farklılaştığını ancak aynı etkinin 7 yaşta görülmediğini ortaya koymaktadır. Bulgular iki dilin etkileşimi ve bunun D1 ve D2 hareket olay anlatımlarına yansımasına ışı tutmaktadır.

Anahtar sözcükler: iki dillilik; hareket olay anlatımı; konuşma-için-düşünme; Türkçe; İngilizce

\section{AUTHOR BIODATA}

Aslı Aktan-Erciyes is an Assistant Professor of Psychology at Kadir Has University, Istanbul. She received her $\mathrm{PhD}$ in Developmental Psychology from Boğaziçi University, İstanbul under supervision of Prof. Ayhan AksuKoç and Prof. Ali İ. Tekcan. She received her MA in Developmental Psychology again from Boğaziçi University. Dr. Aktan-Erciyes is interested in language and cognition interactions, and she uses bilingualism as a tool to study this interaction. One line of her research investigates how early and intense exposure to second language affects first language and vice versa. She is also interested in narrative development and event conceptualization. She follows a developmental perspective in her research and try to integrate converging evidence from multi-level sources. 